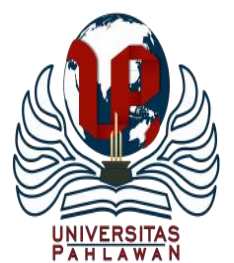

Edukatif : Jurnal Ilmu Pendidikan Volume 3 Nomor 5 Tahun 2021 Halm 2217 - 2231

EDUKATIF: JURNAL ILMU PENDIDIKAN

Research \& Learning in Education

https://edukatif.org/index.php/edukatif/index

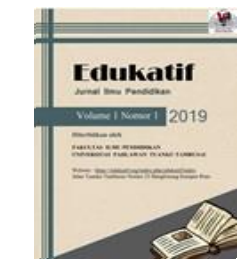

\title{
Pengembangan Bahan Ajar E-Book Berbasis Flipbook sebagai Pendukung Pembelajaran Administrasi Pajak dengan Kompetensi Dasar PPh Pasal 21
}

\author{
Anisah Candra Meidita ${ }^{1 凶}$, Joni Susilowibowo ${ }^{2}$ \\ Universitas Negeri Surabaya, Indonesia ${ }^{1,2}$ \\ E-mail : anisah.17080304080@ mhs.unesa.ac.id ${ }^{1}$, jonisusilowibowo@ unesa.ac.id $^{2}$
}

\begin{abstract}
Abstrak
Pembelajaran secara jarak jauh serta diterapkannya penggunaan K13 menyebabkan perubahan dibidang pendidikan, dimana dibutuhkan penyesuaian dalam kegiatan belajar mengajar. Hal ini terjadi akibat keterbatasan waktu yang tidak optimal sehingga perlu bantuan teknologi informasi yang menjadi perantaranya. Tujuan penelitian untuk menganalisis produk yang telah dikembangkan, untuk menganalisis kelayakan produk, untuk mengetahui respon siswa. Jenis penelitian yaitu pengembangan. Penggunaan model pengembangan yaitu 4D. Peneliti menerapkan tahapan define, design, dan development. Hasil penelitian yaitu produk yang dikembangkan berupa e-book berbasis flipbook materi PPh pasal 21, dimana ditujukan bagi XI AKL 2 SMK Negeri 2 Buduran Sidoarjo. Selanjutnya, analisis kelayakan produk mendapatkan rata-rata validasi para ahli dengan menunjukkan kriteria sangat layak. Lalu untuk analisis respon siswa mendapatkan rata-rata dengan menunjukkan kriteria sangat memahami.
\end{abstract}

Kata Kunci: Bahan Ajar; Model Pengembangan 4D; PPh Pasal 21.

\begin{abstract}
Distance learning and the implementation of the use of K13 have caused changes in the field of education, where adjustments are needed in teaching and learning activities. This happens due to time constraints that are not optimal so that it needs the help of information technology as an intermediary. The purpose of the research is to analyze the product that has been developed, to analyze the feasibility of the product, to determine student responses. The type of research is development. The use of the development model is $4 D$. Researchers apply the stages of define, design, and development. The results of the research are the product developed in the form of an e-book based on the article 21 income tax material $(P P h)$, which is intended for class XI AKL 2 SMK Negeri 2 Buduran Sidoarjo. Furthermore, the product feasibility analysis gets an average validation of the experts by showing very feasible criteria. Then for the analysis of student responses to get an average by showing the criteria for very understanding.
\end{abstract}

Keywords: Teaching Materials; 4D Development Model; Income Tax Article 21.

Copyright (c) 2021 Anisah Candra Meidita, Joni Susilowibowo

$\triangle$ Corresponding author

Email : anisah.17080304080@mhs.unesa.ac.id

DOI : https://doi.org/10.31004/edukatif.v3i5.784

ISSN 2656-8063 (Media Cetak)

ISSN 2656-8071 (Media Online)

Edukatif : Jurnal Ilmu Pendidikan Vol 3 No 5 Tahun 2021 p-ISSN 2656-8063 e-ISSN 2656-8071 
2218 Pengembangan Bahan Ajar E-Book Berbasis Flipbook sebagai Pendukung Pembelajaran Administrasi Pajak dengan Kompetensi Dasar PPh Pasal 21 - Anisah Candra Meidita, Joni Susilowibowo

DOI: https://doi.org/10.31004/edukatif.v3i5.784

\section{PENDAHULUAN}

Proses pembelajaran akan dirasakan oleh setiap peserta didik saat menempuh jenjang pendidikan, dimana peserta didik akan mencapai tingkat pendidikan yang berbeda salah satunya adalah sekolah menengah kejuruan (SMK). Dengan adanya jenjang pendidikan tersebut peserta didik akan memiliki keahlian sesuai bidang kompetensinya. Selain itu setiap peserta didik mendapatkan atau menerima ilmu dari segi pengetahuan dan keterampilan yang akan diterapkan saat bekerja dan di kehidupan sehari-hari.

Pada kondisi negara Indonesia, dimana terdampak musibah akibat terjadinya pandemi covid-19 menyebabkan instansi pemerintah melakukan berbagai upaya untuk perubahan dan penyesuaian salah satunya adalah sektor pendidikan. Pada sektor itu telah menerapkan anjuran sesuai kebijakan bahwa setiap jenjang pendidikan melaksanakan kegiatan secara jarak jauh. Selaras dengan Sa'diyah (2021) bahwa proses tersebut sudah tidak menjalankan pembelajaran secara konvensional melainkan pembelajaran digital sehingga membutuhkan bantuan teknologi informasi untuk mencapai keberhasilan proses belajar mengajar.

Menurut Uno (2011) faktor penentu dalam kesuksesan sistem pendidikan jarak jauh diantaranya yaitu perhatian, kepercayaan diri pendidik, pengalaman, dapat mengoperasikan dan kreatif penggunaan alat, hingga dapat dengan mudah bersosialisasi terhadap peserta didik. Melalui guru selaku pendidik merupakan fasilitator bagi peserta didik dalam memberikan materi yang diajarkan hingga metode pembelajaran yang nantinya diterapkan sehingga peserta didik tetap akan menerima atau mendapatkan pengetahuan dan keterampilan meskipun menggunakan sistem pembelajaran secara daring tersebut. Akan tetapi sistem pembelajaran secara daring tersebut tidak sepenuhnya dilakukan setiap hari, dimana pada kondisi di lapangan juga menggunakan sistem pembelajaran tatap muka atau disebut dengan luring.

Dalam sistem kegiatan pembelajaran secara luring dan daring, setiap sekolah menengah kejuruan (SMK) memiliki upaya untuk mengimplementasikan kurikulum 2013 atau disingkat dengan K13. Menurut Rumahlatu et al. (2016) bahwa komponen implementasi kurikulum 2013 yang sangat penting adalah kompetensi guru dimana berupa pengetahuan, keterampilan, dan sikap yang akan digambarkan dalam tindakan yang baik dan bertanggungjawab dalam menjalankan tugasnya sebagai agen pembelajaran. Hal itu terjadi, karena guru atau pendidik tersebut dituntut untuk sigap dalam menyiapkan materi pembelajaran, strategi, model, perangkat, metode, dan gaya pembelajaran sehingga akan menciptakan suasana kelas yang menyenangkan, kondusif dan optimal. Dengan menghasilkan tujuan proses belajar, guru perlu mengimplementasikan pendekatan yang sesuai kepada peserta didik (Rostika dan Prihantini, 2019). Menurut Masithoh (2018) bahwa kegiatan belajar berhubungan dengan guru, siswa, proses pembelajaran, dan kurikulum. Penggunaan pembelajaran Kurikulum 2013 disebut dengan siklus pembelajaran 7M, kemudian memuat tahapan mengagumi, menghayati, meneliti, mewujudkan, mengkolaborasi, mengaktualisasi, dan memberi. Sedangkan Menurut J.G. Dyer and C. M. Christensen (dalam Pratiwi dan Rochmawati, 2019) pada proses kegiatan dengan K13 tersebut menggunakan pendekatan saintifik, maksudnya adalah bahwa pembelajaran tersebut akan berpusat pada peserta didik yang nanti diharapkan mampu untuk mengimplementasikan upaya 5M yaitu mengamati, mempertanyakan, menguji coba, mengasosiasikan serta yang terakhir yaitu memperhubungkan jaringan. Hal tersebut selaras bahwa pembelajaran melibatkan pendekatan saintifik dimana terdapat keterampilan proses seperti 5M (mengamati, menanya, mengumpulkan informasi, mengasosiasikan, mengomunikasikan) (Hosnan, 2016).

Penerapan pembelajaran secara luring dan daring serta diterapkannya penggunaan K13 berdampak pada proses belajar sehingga mengalami keterbatasan waktu dan tidak optimal. Oleh karena itu, bahan ajar dapat dijadikan atau difungsikan sebagai alat untuk mendukung proses pembelajaran. Menurut Majid (2017) bahan ajar merupakan seperangkat bahan mulai dari tertulis hingga tidak tertulis, dimana akan mempermudah pendidik mencapai proses kegiatan pembelajaran. Maka, dari bahan ajar tersebut peserta didik dengan mudah memahami pembelajaran sebab ia akan melihat kompetensi yang terpadu dari hasil penyusunan secara 
2219 Pengembangan Bahan Ajar E-Book Berbasis Flipbook sebagai Pendukung Pembelajaran Administrasi Pajak dengan Kompetensi Dasar PPh Pasal 21 - Anisah Candra Meidita, Joni Susilowibowo

DOI: https://doi.org/10.31004/edukatif.v3i5.784

sistematis. Menurut Kirana dan Susilowibowo (2020) pendidik dan peserta didik memerlukan penunjang pembelajaran, dimana bahan ajar dijadikan sumber belajar tersebut. Bahan ajar dalam kegiatan pembelajaran akan melibatkan guru dan peserta didik, dimana terdapat aspek untuk memudahkan proses pemberian informasi terkait materi yang sedang diajarkan sehingga bahan ajar tersebut akan dibuat secara sistematis. Tentunya dengan bahan ajar yang telah dirangkai tersebut akan memudahkan penyerapan informasi oleh peserta didik (Rahmawati dan Susanti, 2019).

Menurut Majid (2017) bahan ajar dapat dikelompokkan meliputi: (1) bahan ajar cetak, (2) bahan ajar dengar, (3) bahan ajar pandang, (4) bahan ajar interaktif. Hal ini juga didukung oleh Menurut Dewi dan Rohayati (2012) selain bahan ajar cetak, ada pula bahan ajar interaktif. Menurut Fitriani dan Rohayati (2019) buku ajar termasuk contoh dari bahan ajar dimana dapat ditemui pada saat kegiatan pembelajaran tersebut berlangsung. Menurut Widiyawati dan Susanti (2017) modul merupakan contoh dari bahan ajar yang telah dicetak. Tidak hanya itu, terdapat pula bahan ajar yang termasuk belum atau non cetak. Menurut Tania dan Susilowibowo (2017) modul elektronik merupakan bahan ajar yang menerapkan teknologi informasi dan komunikasi. Buku elektronik adalah contoh dari bahan ajar TIK (Fitriani dan Rohayati, 2019).

Menurut Michael F. Suarez dan Wooudhuysen (2013) bahwa buku elektronik merupakan teks yang diproduksi dan diterbitkan melalui komputer atau perangkat digital sehingga komponen selain teks tersebut dapat ditambahkan suara, gambar, film/video/grafis yang nantinya fitur-fitur tersebut akan mewakilkan buku elektronik. Menurut Yulaika et al. (2020) isi e-book akan memuat mulai dari kompetensi dasar, lalu indikator pencapaian kompetensi, hingga materi-materi yang nantinya akan dievaluasi melalui pengerjaan latihan soal. Selain itu tampilan e-book tersebut akan didesain dengan warna yang menarik, hal itu didukung dengan gambar, tulisan, video, hingga audio. Bahan ajar berbasis elektronik berupa $e$-book tersebut nantinya akan dikombinasikan dengan aplikasi atau software. Menurut Hamid (2021) dalam penyajian flipbook dapat memudahkan pemahaman peserta didik sebab terdapat gambar animasi. Lalu pada penggunaan, pemanfaatan dan pengoperasian teknologi yang digunakan tersebut memiliki tolak ukur untuk dijadikan pacuan dalam berkembang. Hal itu memiliki alasan karena teknologi sudah semakin maju dan pesat, tentunya menjadikan guru serta peserta didik perlu membiasakan diri dibidang teknologi, memiliki keahlian teknologi, dan mengalami perubahan yang meningkat dibidang teknologi.

SMK Negeri 2 Buduran Sidoarjo memiliki beragam pilihan jurusan, akan tetapi peneliti memfokuskan dengan jurusan Akuntansi dan Keuangan. Lembaga dimana jurusan tersebut memiliki mata pelajaran administrasi pajak. Dari mata pelajaran tersebut memuat kompetensi dasar yang perlu dicapai dalam suatu kegiatan pembelajaran salah satunya berupa pajak penghasilan $(\mathrm{PPh})$ pasal 21. Hasil observasi awal kepada guru administrasi pajak mendapatkan hasil bahwa dibutuhkan pengembangan bahan ajar dimana memuat materi PPh pasal 21 sehingga produk ini nantinya akan mendukung proses pembelajaran sekaligus menarik peserta didik. Selanjutnya, sebagian besar peserta didik lebih cenderung kesulitan saat diberikan berbagai pertanyaan seputar materi tersebut. Hal ini terjadi karena mengalami kesulitan dalam teori/pemahaman hingga perhitungannya. Selain itu, peserta didik hanya memiliki pegangan buku paket dari hasil pinjaman perpustakaan. Tentunya dalam hal ini peserta didik tidak memiliki kepemilikan seutuhnya dalam buku pegangan sehingga guru membutuhkan inovasi yang kreatif dan inovatif agar dapat diberikan kepada peserta didik tersebut. Tidak hanya itu, guru dapat melatih keterampilan dibidang teknologi.

Jadi dari permasalahan-permasalahan tersebut akan memicu untuk membutuhkan tambahan berupa pengembangan bahan ajar e-book berbasis flipbook. Dari pengembangan tersebut, diharapkan guru selaku pendidik dapat terbantu dalam penyampaian materi saat mengajar hingga memiliki tambahan kemampuan dibidang teknologi dan peserta didik dapat menguasai materi secara mandiri saat proses pembelajaran jarak jauh diterapkan hingga pengoperasian aplikasi dibidang teknologi. Tentunya tanpa disadari akan menumbuhkan antusias serta semangat belajar karena memiliki bahan ajar yang cukup unik dan menarik dimana kalangan peserta didik masih belum pernah merasakan sebelumnya. Dari pengembangan tersebut 
2220 Pengembangan Bahan Ajar E-Book Berbasis Flipbook sebagai Pendukung Pembelajaran Administrasi Pajak dengan Kompetensi Dasar PPh Pasal 21 - Anisah Candra Meidita, Joni Susilowibowo

DOI: https://doi.org/10.31004/edukatif.v3i5.784

dapat dengan mudah mengakses dengan berbantuan android. Tentunya tanpa ada keterbatasan waktu untuk belajar memahami materi PPh pasal 21.

Jurnal yang mendukung untuk penelitian ini, diantaranya yaitu pertama Pratiwi dan Rochmawati (2019) memiliki kesimpulan bahwa produk e-book interaktif yang digunakan di mata pelajaran praktikum akuntansi lembaga dikatakan sangat layak. Hal ini didapatkan dari rata-rata 4 komponen dengan presentase 84,34\%. Lalu jurnal kedua Kirana dan Susilowibowo (2020) memiliki kesimpulan produk e-book yang digunakan dikatakan sangat layak dengan rata-rata para ahli sebesar 85,6\%, sehingga dapat dijadikan sumber belajar. Selanjutnya jurnal ketiga Fitriani dan Rohayati (2019) memiliki kesimpulan bahwa produk e-book berbasis android yang digunakan di administrasi pajak dikatakan sangat baik, dimana dengan mendapatkan hasil $84,71 \%$ dari rata-rata para ahli. Selanjutnya jurnal keempat dari Widiyawati dan Susanti (2017) memiliki kesimpulan modul yang dikembangkan melalui pelajaran administrasi pajak dikatakan sangat layak, dimana dengan rata-rata 85,75\%. Jurnal kelima Tania dan Susilowibowo (2017) memiliki kesimpulan bahwa e-modul yang digunakan pada materi ayat jurnal penyesuaian dikatakan sangat layak, dimana didapatkan hasil rata-rata 83\% sehingga dapat dijadikan pendukung proses belajar mengajar. Jurnal keenam Yulaika et al. (2020) memiliki kesimpulan bahwa bahan ajar elektronik berbasis flip book materi perpajakan dikatakan memiliki dampak yang positif, sehingga memiliki hasil pembelajaran dan peningkatan aktivitas.

Artikel ini berjudul "Pengembangan Bahan Ajar E-Book Berbasis Flipbook sebagai Pendukung Pembelajaran Administrasi Pajak dengan Kompetensi Dasar PPh Pasal 21". Sejalan dengan pembahasan tersebut maka tujuan penulisan: (1) Menganalisis proses pengembangan produk E-Book berbasis Flipbook sebagai pendukung pembelajaran administrasi pajak dengan kompetensi dasar PPh pasal 21. (2) Menganalisis proses kelayakan produk E-Book berbasis Flipbook sebagai pendukung pembelajaran administrasi pajak dengan kompetensi dasar PPh pasal 21. (3) Mengetahui respon siswa terhadap produk E-Book berbasis Flipbook sebagai pendukung pembelajaran administrasi pajak dengan kompetensi dasar PPh pasal 21.

Berdasarkan uraian diatas terdapat kebaruan dibandingkan dengan penelitian terdahulu, dimana pada penelitian ini dilakukan pada kelas XI AKL 2 SMK Negeri 2 Buduran yang sedang mengalami pembelajaran secara jarak jauh. Hal ini dikarenakan kondisi pandemi yang belum stabil untuk bisa melakukan pembelajaran secara tatap muka sehingga pendidik dan peserta didik membutuhkan produk yang mendukung dalam proses kegiatan belajar mengajar. Jadi, produk yang mendukung tersebut memiliki tampilan yang menarik dan materi yang lengkap. Sedangkan penelitian terdahulu dilakukan pada kelas XII Akuntansi SMK Negeri di Surabaya, serta saat itu belum mengalami pembelajaran secara jarak jauh sehingga produk yang dikembangkan untuk meningkatkan hasil belajar peserta didik. Dari penelitian Widiyawati \& Susanti (2017) memiliki kesenjangan dimana penelitian tersebut mengembangkan produk berupa bahan ajar cetak yaitu modul materi $\mathrm{PPh}$ pasal 21 untuk meningkatkan capaian hasil belajar karena kesulitan dalam materi tersebut. Namun, dalam kondisi pandemi pendidik dan peserta didik memerlukan bahan ajar berbasis elektronik yang diakses dikondisi apapun sehingga tidak terbatas mempelajari materi tersebut. Pada penelitian Yulaika et al. (2020) yang ditujukan bagi kelas XI MA Al Hayatul Islamiyah berupa bahan ajar elektronik berbasis flipbook memiliki persamaan dengan penelitian ini, dimana pendidik menggunakan bahan ajar dari penerbit tanpa membuat secara mandiri sehingga pada penelitian terdahulu dan penelitian ini telah membuat isi produk yang terdiri dari materi perbab, gambar, video, bahan diskusi, soal latihan, dan rangkuman. Akan tetapi memiliki perbedaan, dimana pada penelitian sebelumnya produk tersebut dioperasikan melalui laptop dimana dibagikan dengan cara mengirimkan bentuk aplikasi dengan ekstensi exel. Oleh karena itu, penelitian tersebut akan disempurnakan oleh peneliti dimana produk berbasis android. Produk dibagikan berupa APK sehingga mudah untuk mengunduhnya. Selain itu, isi produk disempurnakan dengan mengacu 5M (mengamati, menanya, mengumpulkan informasi, mengasosiasikan, mengomunikasikan) serta tambahan audio. Maka, penelitian yang dilakukan oleh peneliti penting dilakukan karena memudahkan mengembangkan produk berbasis elektronik sehingga dapat dijadikan suatu inovasi untuk memotivasi belajar serta memudahkan pemahaman peserta didik. 
2221 Pengembangan Bahan Ajar E-Book Berbasis Flipbook sebagai Pendukung Pembelajaran Administrasi Pajak dengan Kompetensi Dasar PPh Pasal 21 - Anisah Candra Meidita, Joni Susilowibowo

DOI: https://doi.org/10.31004/edukatif.v3i5.784

\section{METODE PENELITIAN}

Jenis penelitian yaitu pengembangan atau disebut dengan Research and Develompment (R\&D). Model pengembangan berupa 4D, dimana Menurut Trianto (2017) tahapan yang dilakukan oleh Thiagaran meliputi define, design, development, dan dissemination. Tahapan bagian pertama define memiliki beberapa syarat yang dapat dibagi menjadi lima diantaranya yaitu (1) analisis awal akhir, (2) analisis peserta didik, (3) analisis tugas, (4) analisis konsep, (5) perumusan indikator pencapaian kompetensi. Selanjutnya tahapan kedua design tersebut dapat dibagi menjadi dua diantaranya yaitu (1) penyusunan format produk, dan (2) mendesain produk awal e-book. Lalu tahapan ketiga development dibagi menjadi beberapa langkah diantaranya yaitu (1) produksi, (2) telaah para ahli, (3) menganalisis hasil telaah dan revisi, (4) validasi para ahli, (5) menganalisis hasil validator, (6) menguji secara terbatas, (7) menganalisis hasil uji coba terbatas, dan (8) validitas produk. Dan tahapan terakhir disseminate, dimana peneliti hanya menjalankan tiga tahapan. Hal ini dikarenakan oleh keterbatasan tenaga serta kondisi pandemi yang tidak memungkinkan sehingga peneliti tidak menerapkan pengemasan, penyebaran ataupun pengadopsian. Subjek penelitian tersebut terdiri dari ahli materi, ahli bahasa, ahli grafis, dan peserta didik XI AKL 2 di SMK Negeri 2 Buduran Sidoarjo.

Data tergolong kualitatif dan kuantitatif. Dari pemaparan tersebut, maka maksud dari kualitatif didapatkan dari hasil wawancara dengan selaku guru atau pendidik untuk mengetahui informasi seputar permasalahan di kelas ataupun sekolah hingga lembar telaah para ahli, sedangkan kuantitatif hasil penelitian berupa angka dimana memuat dari respon peserta didik hingga validasi para ahli. Instrumen pengumpulan data yang dilakukan oleh peneliti yaitu interview atau wawancara, dimana ditujukan kepada pendidik mata pelajaran administrasi pajak XI AKL 2 SMK Negeri 2 Buduran. Selanjutnya angket terbuka, dimana ditujukan kepada tiga para ahli untuk mengisi lembar telaah yang telah diolah dari penyesuaian berdasarkan BSNP (2014). Lalu terakhir angket tertutup, dimana ditujukan kepada tiga para ahli untuk mengisi lembar validasi dengan hasil olahan dari peneliti yang telah disesuaikan dengan (BSNP, 2014).

Teknik analisis data akan memiliki beberapa tahapan diantaranya yaitu (1) analisis data telaah para ahli. Untuk mencapai hasil data telaah tersebut, maka menggunakan data kualitatif maksudnya yaitu penggunaan data tersebut terlihat dari angket yang sebelumnya telah dibagikan kepada tiga para ahli. (2) analisis data validasi para ahli, dimana sesuai dengan deskriptif kuantitatif. Maksud dari deskriptif yaitu mencantumkan hasil analisis para ahli ke dalam lembar telaah untuk dijadikan perubahan atau perbaikan bahan ajar. Sedangkan maksud kuantitatif yaitu hasil analisis yang berada di instrumen tersebut menghasilkan presentase sehingga mengetahui hasil kelayakan bahan ajar e-book berbasis flipbook tersebut. Tahapan ini menggunakan skala likert.

Tabel 1. Kriteria Penilaian Para Ahli Materi/Bahasa/Grafis

\begin{tabular}{cc}
\hline Kriteria Penilaian & Nilai/Skor \\
\hline Sangat Baik & 5 \\
\hline Baik & 4 \\
\hline Sedang & 3 \\
\hline Tidak Baik & 2 \\
\hline Sangat Tidak Baik & 1 \\
\hline Sumber: Riduwan (2003) dan dimodifikasi oleh peneliti &
\end{tabular}

Setelah menganalisis, maka mendapatkan hasil yang telah divalidasi oleh para ahli. Dari hasil tersebut, selanjutnya akan dihitung menggunakan rumus seperti dibawah ini:

Presentase Kelayakan $=\frac{\text { Jumlah Skor Keseluruhan }}{\text { Skor Maksimal }} \times 100 \%$

Sehingga untuk mengetahui kelayakan bahan ajar e-book berbasis flipbook akan didapatkan dari hasil sesuai kriteria interpretasi. 
2222 Pengembangan Bahan Ajar E-Book Berbasis Flipbook sebagai Pendukung Pembelajaran Administrasi Pajak dengan Kompetensi Dasar PPh Pasal 21 - Anisah Candra Meidita, Joni Susilowibowo

DOI: https://doi.org/10.31004/edukatif.v3i5.784

Tabel 2. Kriteria Interpretasi Para Ahli Materi/Bahasa/Grafis

\begin{tabular}{cc}
\hline Presentase (\%) & Kriteria Interpretasi \\
\hline $0 \%-20 \%$ & Sangat Tidak Layak \\
\hline $21 \%-40 \%$ & Tidak Layak \\
\hline $41 \%-60 \%$ & Cukup Layak \\
\hline $61 \%-80 \%$ & Layak \\
\hline $81 \%-100 \%$ & Sangat Layak \\
\hline Sumber: Riduwan (2003) dan dimodifikasi oleh peneliti
\end{tabular}

Maka untuk mendapatkan hasil interpretasi validasi para ahli tergolong layak ataupun sangat layak jika mencapai rata-rata presentase $\geq 61 \%$. Lalu pada analisis angket respon peserta didik, akan dilakukan dengan uji coba terbatas. Oleh karena itu, peserta didik dengan jumlah 20 diberikan lembar angket dimana berguna untuk mengisi penilaian setelah menggunakan dan mengoperasikan produk tersebut. Menurut Riduwan (2003) angket tersebut akan dianalisis secara kuantitatif berdasarkan skala guttman.

Tabel 3. Kriteria Penilaian Skala Guttman

\begin{tabular}{cc}
\hline Kriteria Penilaian & Nilai/Skor \\
\hline Ya (Y) & 1 \\
\hline Tidak (T) & 0 \\
\hline Sumber: Riduwan (2003) dan dimodifikasi oleh peneliti &
\end{tabular}

Selanjutnya, setelah mengetahui penilaian respon peserta didik maka dapat dihitung dengan cara sebagai berikut:

$$
\text { Presentase Kelayakan }=\frac{\text { Jumlah Skor Keseluruhan }}{\text { Skor Maksimal }} \times 100 \%
$$

Sehingga setelah mendapatkan hasil analisis dan perhitungan tersebut, akan mendapatkan kriteria interpretasi respon peserta didik. Jadi setelah proses menganalisis hingga menghitung respon angket peserta didik, akan mendapatkan interpretasi $\geq 61 \%$ dimana hasil tersebut tergolong baik jika mencapai presentase tersebut.

Tabel 4. Kriteria Interpretasi Peserta Didik

\begin{tabular}{cc}
\hline Presentase (\%) & Kriteria Interpretasi \\
\hline $0-20$ & Sangat Tidak Memahami \\
\hline $21-40$ & Tidak Memahami \\
\hline $41-60$ & Cukup Memahami \\
\hline $61-80$ & Memahami \\
\hline $81-100$ & Sangat Memahami \\
\hline Sumber: Riduwan (2003) dan dimodifikasi oleh peneliti
\end{tabular}

\section{HASIL DAN PEMBAHASAN PENELITIAN}

\section{Proses Pengembangan Bahan Ajar E-Book Berbasis Flipbook}

Proses pengembangan produk yang telah dilakukan oleh peneliti akan memuat 3 tahapan yaitu define, design, dan develop. Tahapan pertama define tersebut akan berisi analisis awal akhir, peserta didik, tugas, dan konsep. Maka, analisis awal akhir untuk produk yang dikembangkan memuat sesuai kurikulum K13 seperti 5M (mengamati, menanya, mengumpulkan informasi, mengasosiasikan, mengomunikasikan). Berdasarkan proses tersebut akan ditujukan bagi pendidik dan peserta didik yang berada di SMK dengan pilihan mata pelajaran administrasi pajak. Sesuai analisis selama penelitian, pendidik membutuhkan tambahan bahan ajar yang memuat materi pajak penghasilan ( $\mathrm{PPh}$ ) pasal 21 serta diperlukan tambahan adaptasi dengan teknologi.

Selain itu, analisis peserta didik memiliki hasil bahwa peserta didik tidak memiliki pegangan bahan ajar secara pribadi sehingga menyebabkan kesulitan dalam proses belajar. Peserta didik juga merasa kesulitan 
dengan materi tersebut, dimana diperlukannya pemahaman tambahan yang memicu untuk memotivasi agar lebih giat belajar dan mencoba untuk mengerjakkan latihan soal dengan high order thinking skills (HOTS).

Analisis tugas memiliki maksud bahwa peserta didik mengimplementasikan sesuai dengan muatan $5 \mathrm{M}$. Pertama yaitu mengamati, dimana peserta didik akan melakukan kegiatan pengamatan dengan tampilan video yang ada pada produk bahan ajar. Pada tampilan video tersebut akan sesuai dengan materi perbab. Kedua yaitu menanya, dimana peserta didik bertanya bilamana merasa kesulitan ataupun memiliki berbagai pertanyaan terkait proses mengamati. Ketiga yaitu mengumpulkan informasi, dimana memuat materi-materi yang telah disesuaikan dengan KD dan indikator pencapaian kompetensi. Dari materi-materi tersebut juga diselipkan dengan catatan kecil sebagai pengingat dan catatan kecil sebagai info tambahan. Keempat yaitu mengasosiasikan, dimana memuat pertanyaan untuk diskusi secara individu ataupun kelompok. Kelima yaitu mengomunikasikan, dimana perlu dilakukan kegiatan presentasi secara individu ataupun kelompok. Selain itu peserta didik dapat mengerjakan latihan soal secara individu dengan tipe soal pilihan ganda dan uraian. Hal ini dapat menilai tingkat pemahaman dalam sebuah pembelajaran. Serta terdapat juga rangkuman pembelajaran. Jadi, analisis tugas yang telah dijabarkan tersebut akan termuat pada setiap bab yang ada pada produk bahan ajar.

Analisis konsep memiliki maksud bahwa administrasi pajak dengan materi pajak penghasilan ( $\mathrm{PPh})$ pasal 21 termuat dalam kompetensi dasar. Hal ini sesuai dengan silabus yang telah menunjukkan materi tersebut berada pada KD 3.4 sampai 3.6. Oleh karena itu, dapat dijadikan acuan untuk menyusun produk bahan ajar karena dapat diolah sesuai dengan indikator pencapaian kompetensi.

Tahapan kedua design yaitu tahapan perancangan dimana memuat produk bahan ajar yang disesuaikan dengan format dan desain awal. Oleh karena itu, tahapan tersebut dapat menarik pengguna seperti pendidik dan peserta didik. Hal ini dimaksudkan bahwa diperlukannya tampilan seperti cover, pemilihan warna yang setema, tipe tulisan, gambar-gambar yang termuat pada materi hingga logo yang ada pada produk tersebut.

Pada tampilan design awal produk terdapat logo kampus dimana ditujukan untuk menunjukkan produk yang dikembangkan oleh peneliti berasal dari Universitas Negeri Surabaya atau UNESA. Sebuah produk yang dikembangkan membutuhkan tanda pengenal sehingga logo kampus merupakan salah satu langkah yang tepat untuk dipilih. Tentunya dalam memilih logo tersebut perlu diperhatikan ukuran dan kualitas, sebab dengan ukuran yang normal dan kualitas yang baik maka logo yang ditampilkan tidak terlihat pecah.

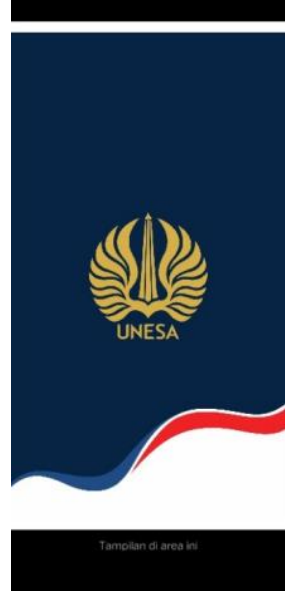

Gambar 1 : Tampilan Design Awal Produk

Sumber: diolah peneliti (2021)

Selain itu terdapat tampilan untuk memulai membuka menu awal dalam produk yang dikembangkan. Hal ini memiliki maksud peneliti dapat menuntun para pembaca agar secara benar dan urut membuka produk yang nantinya akan dipelajari. Dari simbol mulai tersebut para pembaca dapat mengklik agar dapat melihat tampilan selanjutnya. Lalu untuk simbol silang dapat diklik jika memilih keluar dari program. 
2224 Pengembangan Bahan Ajar E-Book Berbasis Flipbook sebagai Pendukung Pembelajaran Administrasi Pajak dengan Kompetensi Dasar PPh Pasal 21 - Anisah Candra Meidita, Joni Susilowibowo

DOI: https://doi.org/10.31004/edukatif.v3i5.784

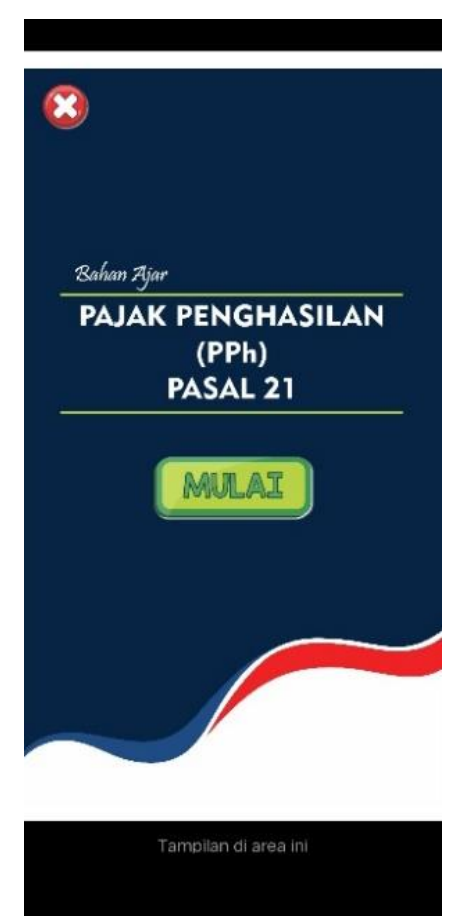

Gambar 2 : Tampilan Membuka Menu Awal Produk Sumber: diolah peneliti (2021)

Lalu, terdapat berbagai simbol dan keterangan yang nantinya dimaksudkan agar pembaca dapat mengerti arti sebuah simbol tersebut. Tentunya simbol yang dirancang oleh peneliti merupakan simbol yang memang dibutuhkan untuk bahan ajar. Dari keterangan simbol tersebut memilih tipe tulisan yang sederhana dimana agar pembaca mudah memahami. Selain itu, ukuran tulisan perlu diperhatikan sebab jika tipe tulisan mudah terbaca akan tetapi ukuran yang dipilih cukup kecil maka pembaca akan merasa kesulitan untuk membaca dan mengerti maksud tulisannya. Maka, membutuhkan keseimbangan antara ukuran dan tipe tulisan.

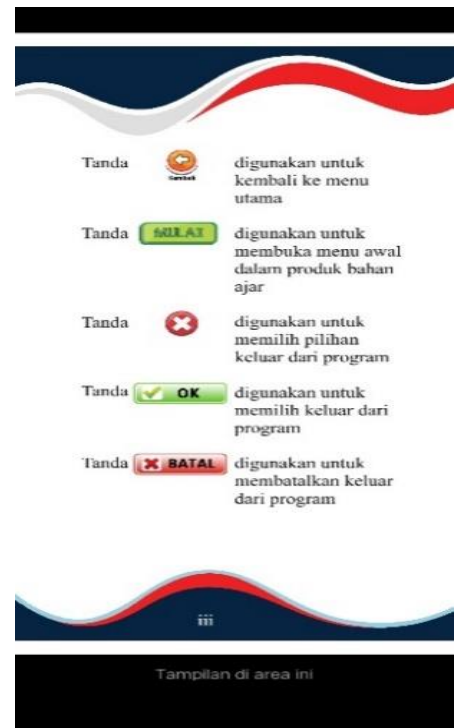

Gambar 3 : Berbagai Simbol dan Keterangan Produk Sumber: diolah peneliti (2021) 
Pada rancangan produk juga perlu memilih warna yang setema. Misalnya pada produk yang dikembangkan oleh peneliti menggunakan warna biru dan merah. Maka, warna tabel produk tersebut yaitu berbagai warna biru dengan satu kesatuan.

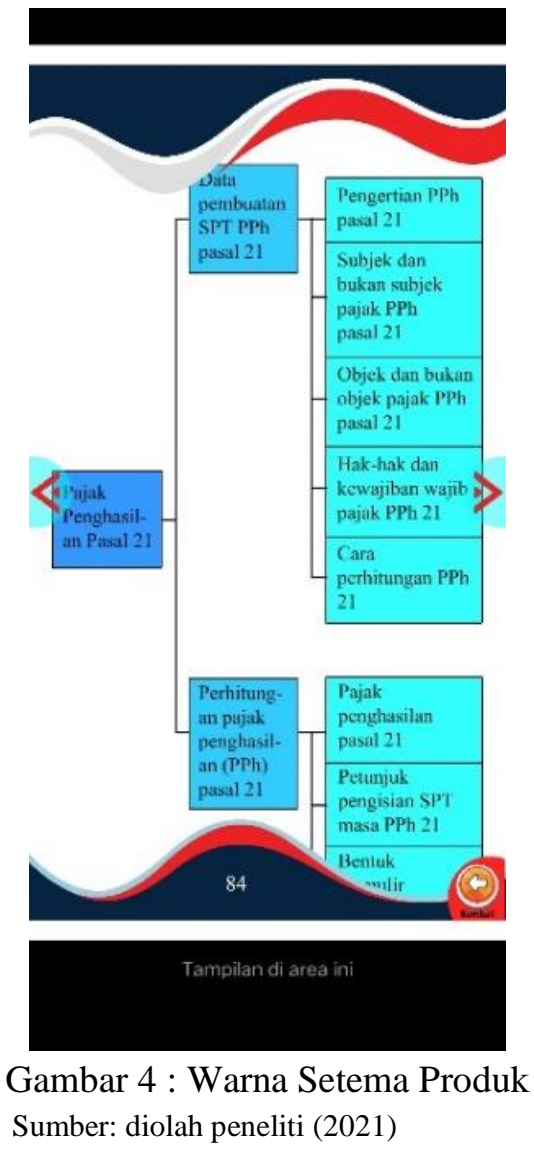

Tahapan ketiga develop yaitu tahapan pengembangan yang telah disusun dan menghasilkan sesuai dengan draft I dimana nantinya dapat diproses ke tahapan selanjutnya. Oleh karena itu, setelah produk tersebut telah selesai peneliti melakukan kegiatan telaah, validasi, dan uji coba terbatas. Kegiatan telaah tersebut akan ditujukan kepada para ahli dimana diberikannya komentar ataupun saran untuk memperbaiki produk yang sedang dikembangkan. Ahli pertama yaitu ahli materi memiliki komentar bahwa penulisan tujuan pembelajaran dihapus sehingga hanya mencantumkan KD dan indikator pencapaian kompetensi, audio diganti lebih klasik sehingga menjadi musik piano. Ahli kedua yaitu ahli bahasa memiliki komentar bahwa penulisan kata lebih disesuaikan dengan PUEBI. Dan ahli ketiga yaitu ahli grafis memiliki komentar bahwa cover diganti dengan gambar nyata (bukan animasi), ditambahkan kalimat mengenai flipbook, KD dan IPK diberikan tanda mana saja yang menunjukkan pembelajaran I, II, III, dan diberikan warna yang setema pada tabel peta konsep. Jadi, dari berbagai komentar/saran/masukkan yang telah didapatkan dari para validator tersebut akan diperbaiki agar dapat menyempurnakan perangkat bahan ajar. Setelah proses telaah selesai maka dapat melanjutkan ke proses validasi, dimana termuat nilai yang nantinya dianalisis untuk mengetahui tingkat kelayakan. Proses validasi tersebut memiliki lembar dengan berbagai pertanyaan yang nantinya akan diisi oleh validator. Setelah itu, dapat dilakukan uji coba secara terbatas ke peserta didik.

Tahap keempat dissemination yaitu tahapan yang tidak dilakukan oleh peneliti. Hal ini dikarenakan oleh keterbatasan tenaga serta kondisi pandemi yang tidak memungkinkan untuk dilakukan tahap ini sehingga peneliti tidak menerapkan pengemasan, penyebaran ataupun pengadopsian. 
2226 Pengembangan Bahan Ajar E-Book Berbasis Flipbook sebagai Pendukung Pembelajaran Administrasi Pajak dengan Kompetensi Dasar PPh Pasal 21 - Anisah Candra Meidita, Joni Susilowibowo

DOI: https://doi.org/10.31004/edukatif.v3i5.784

\section{Kelayakan Bahan Ajar E-Book Berbasis Flipbook}

Hasil kelayakan isi dan penyajian materi didapatkan dari ahli materi 1 dan 2 yaitu ahli materi 1 dosen PAK UNESA sekaligus dosen pembimbing, sedangkan ahli materi 2 yaitu pendidik administrasi pajak SMK Negeri 2 Buduran Sidoarjo.

Tabel 5. Hasil Validasi Kelayakan Materi

\begin{tabular}{clcccc}
\hline No. & \multicolumn{1}{c}{ Komponen } & Ahli Materi 1 & Ahli Materi 2 & Presentase & Kriteria \\
\hline 1. & Cakupan materi & $100 \%$ & $100 \%$ & $100 \%$ & Sangat Layak \\
\hline 2. & Akurasi materi & $80 \%$ & $80 \%$ & $80 \%$ & Layak \\
\hline 3. & Kemutakhiran dan kontekstual & $86,66 \%$ & $86,66 \%$ & $86,66 \%$ & Sangat Layak \\
\hline 4. & Ketaatan hukum dan UU & $100 \%$ & $100 \%$ & $100 \%$ & Sangat Layak \\
\hline 5. & Pendukung penyajian materi & $86,66 \%$ & $86,66 \%$ & $86,66 \%$ & Sangat Layak \\
\hline 6. & Teknik penyajian & $92 \%$ & $88 \%$ & $90 \%$ & Sangat Layak \\
\hline 7. & Pendukung penyajian materi & $85 \%$ & $90 \%$ & $87,5 \%$ & Sangat Layak \\
\hline 8. & Penyajian pembelajaran & $85 \%$ & $90 \%$ & $87,5 \%$ & Sangat Layak \\
\hline 9. & Kelengkapan penyajian & $90 \%$ & $100 \%$ & $95 \%$ & Sangat Layak \\
\hline & Rata-Rata Kelayakan Materi & \multicolumn{5}{c}{$90,36 \%$} \\
\hline & Kriteria Kelayakan Materi & \multicolumn{5}{c}{ Sangat Layak } \\
\hline
\end{tabular}

Sumber: diolah peneliti (2021)

Pada tabel itu rata-rata kelayakan materi yang diperoleh dari analisis validator materi 1 dan 2 memiliki presentase 90,36\% dengan kriteria sangat layak. Hal itu disebabkan berbagai aspek meliputi: (1) cakupan materi, dimana mendapatkan skor $100 \%$, karena menurut validator telah sesuai KD yang ditetapkan seperti diatur oleh Perdirjen Dikdasmen Nomor 464/D.D5/KR/2018. (2) akurasi materi, dimana mendapatkan skor $80 \%$. Menurut validator telah tergolong sesuai dengan fakta, konsep, dan prosedur. (3) kemutakhiran dan kontekstual, dimana mendapatkan skor $86,66 \%$ karena kesesuaian materi dan keterkinian fitur sehingga meningkatkan perkembangan teknologi. (4) ketaatan hukum dan UU, dimana mendapatkan skor 100\% karena tidak mengandung unsur SARA yang dilarang oleh hukum dan UU. (5) pendukung penyajian materi, dimana mendapatkan skor $86,66 \%$ karena menurut validator terdapat karakteristik $5 \mathrm{M}$ sehingga dapat menerapkan kegiatan belajar sesuai dengan prosedur. Nantinya dari kegiatan $5 \mathrm{M}$ tersebut dapat meningkatkan kualitas belajar yang baik, kondusif, dan terencana. (6) teknik penyajian, dimana pada pendukung teknik penyajian mendapatkan skor $90 \%$ karena menurut validator terdapat konsistensi, kelogisan, keruntutan, koherensi dalam sebuah penyajian bahan ajar. (7) pendukung penyajian materi, dimana mendapatkan skor $87,5 \%$ karena sesuai penggunaan ilustrasi yang telah dijabarkan dalam bahan ajar, pembangkit motivasi yang dapat membuat peserta didik lebih semangat dan aktif untuk mempelajari materi, penyajian contoh soal yang dibuat dengan keterkinian ranah peserta didik, peta konsep dan rangkuman yang memudahkan pemahaman peserta didik, kunci jawaban yang dapat dijadikan koreksi di akhir proses pembelajaran, serta sumber rujukan untuk mengetahui lebih lanjut mengenai materi bahan ajar tersebut. (8) penyajian pembelajaran, dimana mendapatkan skor $87,5 \%$ karena terdapat perubahan mengenai keaktifan peserta didik. Selain itu, kreatifitas penyajian dapat juga menyebabkan peserta didik tertarik untuk melihat dan mempelajari bahan ajar. (9) kelengkapan penyajian, dimana mendapatkan skor 95\% karena terdapat pendahuluan, daftar isi, glosarium, dan daftar pustaka yang berguna untuk menyempurnakan isi dari produk tersebut. Tentunya unsur tersebut perlu dilampirkan agar suatu produk dapat terbilang kompleks atau lengkap.

Selanjutnya kelayakan bahasa didapatkan dari dosen FBS UNESA dengan presentase 80,47\% dimana tergolong kriteria layak. Berdasarkan hasil analisis tersebut memiliki rincian sebagai berikut:

Tabel 6. Hasil Validasi Kelayakan Bahasa

\begin{tabular}{clcc}
\hline No. & \multicolumn{1}{c}{ Komponen } & Presentase & Kriteria \\
\hline 1. & Kesesuian tingkat perkembangan peserta didik & $70 \%$ & Layak \\
\hline 2. & Keterbacaan & $80 \%$ & Layak \\
\hline 3. & Kemampuan motivasi & $80 \%$ & Layak \\
\hline
\end{tabular}


2227 Pengembangan Bahan Ajar E-Book Berbasis Flipbook sebagai Pendukung Pembelajaran Administrasi Pajak dengan Kompetensi Dasar PPh Pasal 21 - Anisah Candra Meidita, Joni Susilowibowo

DOI: https://doi.org/10.31004/edukatif.v3i5.784

\begin{tabular}{rlcc}
\hline 4. & Kelugasan & $80 \%$ & Layak \\
\hline 5. & Koherensi dan keruntutan alur pikir & $80 \%$ & Layak \\
\hline 6. & Kesesuaian kaidan Bahasa Indonesia & $80 \%$ & Layak \\
\hline 7. & Penggunaan istilah dan simbol atau lambang & $93,33 \%$ & Sangat Layak \\
\hline \multicolumn{2}{r}{ Rata-Rata Kelayakan Bahasa } & \multicolumn{2}{c}{$80,47 \%$} \\
\hline \multicolumn{2}{c}{ Kriteria Kelayakan Bahasa } & \multicolumn{2}{c}{ Layak } \\
\hline
\end{tabular}

Sumber: diolah peneliti (2021)

Pada tabel itu memiliki presentase layak disebabkan oleh berbagai komponen meliputi: (1) kesesuaian tingkat perkembangan peserta didik, dimana pada aspek tersebut mendapatkan skor $70 \%$ dengan kriteria layak. Hal ini disebabkan oleh penjelasan konsep dan ilustrasi serta penyesuaian tingkat perkembangan sosio emosional. (2) keterbacaan, dimana mendapatkan skor 80\% dengan kriteria layak, dimana penyajian pesan yang termuat didalam materi yang telah disampaikan pada produk bahan ajar sehingga mengerti maksud materinya. (3) kemampuan motivasi, dimana mendapatkan skor $80 \%$ dengan kriteria layak, dimana terdapat kemampuan bahasa untuk memotivasi serta mendorong peserta didik agar berpikir kritis dalam proses kegiatan belajar. (4) kelugasan, dimana mendapatkan skor $80 \%$ dengan presentase layak. Hal ini disebabkan oleh ketepatan struktur kaidah Bahasa Indonesia serta penggunaan KBBI. (5) koherensi dan keruntutan alur pikir, dimana mendapatkan skor $80 \%$. Hal ini karena terdapat keruntutan atau keterkaitan antara seluruh isi, maksudnya bahwa antara makna yang ada dibahan ajar, bab, sub bab berada dalam satu kesatuan. (6) kesesuaian dengan kaidah Bahasa Indonesia, dimana mendapatkan skor 80\% karena ketepatan ejaan PUEBI. (7) penggunaan istilah dan simbol atau lambang, dimana presentase 93,33\% dikarenakan konsisten dalam penggunaan istilah, simbol atau lambang, dan penulisan kata ilmiah.

Berdasarkan analisis dari peneliti tersebut telah sesuai dengan menurut Sukiman (2012) yang menyatakan bahwa dalam praktik penulisan bahan ajar yang ditujukan bagi peserta didik terdapat 5 cakupan meliputi: (1) bagian pendahuluan, (2) kegiatan belajar, (3) evaluasi dan kunci jawaban, (4) glosarium, (5) daftar pustaka. Maksud dari bagian pendahuluan yaitu terdapat aspek: (a) latar belakang, (b) deskripsi singkat terkait bahan ajar, (c) manfaat, (d) standar kompetensi, (e) KD, (f) peta konsep, (g) petunjuk penggunaan. Lalu maksud dari kegiatan belajar yaitu terdapat aspek meliputi: (a) KD dan indikator, (b) materi pokok, (c) uraian materi berupa penjelasan, contoh, dan ilustrasi, (d) rangkuman, (e) latihan soal, (f) kunci jawaban. Maka syarat bahasa baik dan benar meliputi: (1) bahasa yang digunakan baik dan benar serta komunikatif, (2) menggunakan sapaan kata ganti orang, (3) memilih kalimat yang sederhana, (4) menghindari istilah sangat asing, (5) hindari kalimat pasif dan negatif ganda, (6) menggunakan bantuan ilustrasi seperti tabel, gambar, warna yang membuat peserta didik tertarik dengan penjelasan ilustrasi tersebut sehingga uraian ilustrasi akan menjadi jelas dan menciptakan imajinasi terhadap materi pembelajaran, (7) memberikan ungkapan motivasi, (8) menciptakan kesan bahan ajar yang baik.

Lalu kelayakan grafis didapatkan dari dosen TP UNESA dengan presentase 96,48\% dimana tergolong kriteria sangat layak.

Tabel 7. Hasil Validasi Kelayakan Grafis

\begin{tabular}{clcc}
\hline No. & \multicolumn{1}{c}{ Komponen } & Presentase & Kriteria \\
\hline 1. & Tata letak cover & $95 \%$ & Sangat Layak \\
\hline 2. & Tipografi cover & $100 \%$ & Sangat Layak \\
\hline 3. & Ilustrasi cover & $100 \%$ & Sangat Layak \\
\hline 4. & Desain isi & $97,27 \%$ & Sangat Layak \\
\hline 5. & Ilustrasi memperjelas dan memudahkan pemahaman materi & $86,66 \%$ & Sangat Layak \\
\hline 6. & Ilustrasi isi menimbulkan daya tarik & $100 \%$ & Sangat Layak \\
\hline \multicolumn{2}{r}{ Rata-Rata Kelayakan Grafis } & \multicolumn{2}{c}{ 96,48\% } \\
\hline \multicolumn{2}{c}{ Kriteria Kelayakan Grafis } & \multicolumn{2}{c}{ Sangat Layak } \\
\hline
\end{tabular}

Sumber: diolah peneliti (2021) 
Pada tabel diatas, produk bahan ajar tergolong sangat layak karena memiliki alasan meliputi: (1) tata letak cover, dimana mendapatkan skor 95\% dengan kriteria sangat layak. Hal ini karena terdapat penampilan unsur kesatuan dalam cover tersebut, dan komposisi unsur tata letak telah sesuai. Maksudnya bahwa pemberian judul, pengarang hingga logo telah sesuai dan memiliki pewarnaan yang baik sehingga memperjelas isi produk yang dikembangkan. (2) tipografi cover, dimana mendapatkan skor 100\% dengan kriteria sangat layak. Hal ini karena ukuran huruf dan judul dominan sehingga mempermudah membacanya. Selain itu tidak terdapat banyak kombinasi, serta huruf hias. (3) ilustrasi cover, dimana mendapatkan skor $100 \%$ dengan presentase sangat layak. Hal ini karena kandungan isi atau materi produk yang dikembangkan sesuai dengan gambaran ilustrasi tersebut. (4) desain isi, dimana mendapatkan presentase 97,27\% dengan kriteria sangat layak. Hal ini memiliki alasan bahwa konsisten dalam penempatan judul bab, spasi antar teks, keterangan gambar sehingga penempatan tersebut tidak menganggu tampilan bahan ajar. Lalu tidak banyak jenis huruf atau variasi huruf sehingga tidak berlebihan dalam penggunaan variasinya. (5) ilustrasi memperjelas dan memudahkan pemahaman materi, dimana dengan skor $86,66 \%$ kriteria sangat layak. Hal ini karena terdapat kemampuan dalam mengungkap makna atau arti suatu objek. Selain itu, proposionalitas bentuk yang baik, kesesuaian bentuk dan skala dengan kenyataan yang ada. (6) ilustrasi isi menimbulkan daya tarik, dimana presentase $100 \%$ karena keserasian dengan kenyataan yang ada, hingga kreatif dalam tampilan isi tersebut.

Berdasarkan analisis dari peneliti tersebut telah sesuai dengan menurut Sukiman (2012) yang menyatakan bahwa dalam penggunaan audio, gambar, dan video yang baik perlu memperhatikan hal-hal meliputi: (1) audio digunakan dalam semua fase pembelajaran dimana dari tahapan pendahuluan. (2) sederhana, maksudnya bahwa gambar memiliki komposisi jelas. (3) gambar dengan kualitas bagus seperti indikator yang ingin dicapai. (4) penggunaan video lebih baik diproduksi secara pribadi agar topik dan ranah kompetensi sesuai dengan yang dituju. Oleh karena itu, penggunanya tidak akan merasa bosan untuk mempelajari materi yang telah disajikan.

Jadi, berdasarkan hasil analisis para ahli yang dijabarkan tersebut dapat ditunjukkan dengan rekapan sebagai berikut:

Tabel 8. Rekapitulasi Hasil Validasi Para Ahli

\begin{tabular}{clccc}
\hline No. & & Aspek & Presentase & Kriteria \\
\hline 1. & Materi & $90,36 \%$ & Sangat Layak \\
\hline 2. & Bahasa & $80,47 \%$ & Layak \\
\hline 3. & Grafis & $96,48 \%$ & Sangat Layak \\
\hline & & Rata-Rata Keseluruhan & $89,10 \%$ & Sangat Layak \\
\hline
\end{tabular}

Sumber: diolah peneliti (2021)

Rekapitulasi itu telah menunjukkan presentase sebesar 89,10\%. Menurut Riduwan (2003) bahwa kelayakan sebuah produk bahan ajar mendapatkan rata-rata interpretasi sebesar $\geq 61 \%$. Proses kelayakan produk tersebut akan terpacu sesuai dengan BSNP (2014) dimana terdapat komponen kelayakan isi dan penyajian materi, kelayakan bahasa, dan kelayakan grafis sehingga memilih skala likert untuk mengetahui presentase penilaiannya. Tentunya dari hasil presentase rekapitulasi yang telah dianalisis oleh peneliti sejalan dengan Kirana dan Susilowibowo (2020) yang menunjukkan rerata presentase kelayakan produk sebesar 85,6\% dengan sangat layak. Lalu sejalan juga dengan penelitian dari Fitriani dan Rohayati (2019) yang menunjukkan hasil rekapitulasi $84,71 \%$. Oleh karena itu, produk yang telah dikembangkan oleh peneliti dapat dioperasikan sebagai pendukung proses pembelajaran dengan berbantuan teknologi.

\section{Respon Peserta Didik terhadap Bahan Ajar E-Book Berbasis Flipbook}

Dalam memperolehnya perlu dilakukan uji coba secara terbatas. Dari kegiatan tersebut, perlu membagikan lembar angket beserta produk dalam bentuk APK kepada peserta didik yang berada dikelas XI AKL 2. Setelah mendapatkan hasil dari 20 peserta didik, maka peneliti dapat menganalisis dengan cara menghitung sesuai dengan skala guttman yang nantinya akan menunjukkan hasil kriterianya. 
2229 Pengembangan Bahan Ajar E-Book Berbasis Flipbook sebagai Pendukung Pembelajaran Administrasi Pajak dengan Kompetensi Dasar PPh Pasal 21 - Anisah Candra Meidita, Joni Susilowibowo

DOI: https://doi.org/10.31004/edukatif.v3i5.784

Tabel 9. Rekapitulasi Angket Respon Peserta Didik

\begin{tabular}{clcc}
\hline No. & Komponen & Presentase & Kriteria \\
\hline 1. & Isi & $100 \%$ & Sangat Memahami \\
\hline 2. & Penyajian & $97,85 \%$ & Sangat Memahami \\
\hline 3. & Bahasa & $92,5 \%$ & Sangat Memahami \\
\hline 4. & Grafis & $97,5 \%$ & Sangat Memahami \\
\hline \multicolumn{2}{r}{ Rata-Rata Presentase Angket Peserta Didik } & \multicolumn{2}{c}{ Sangat Memahami } \\
\hline \multicolumn{2}{c}{ Kriteria Presentase Angket Peserta Didik }
\end{tabular}

Sumber: diolah peneliti (2021)

Pada tabel diatas, mendapatkan 96,96\% dengan sangat memahami. Tentunya hasil tersebut memiliki alasan: (1) isi, dimana mendapatkan presentase $100 \%$ karena 20 peserta didik yang menjawab "Ya" untuk aspek materi di produk mempermudah pemahaman. (2) penyajian, dimana mendapatkan presentase $97,85 \%$ karena terdapat aspek meliputi: (a) ketertarikan untuk mempelajari materi dengan 20 peserta didik menjawab "Ya", (b) meningkatkan motivasi untuk mempelajari materi dengan 19 peserta didik menjawab "Ya", (c) petunjuk penggunaan mudah dipahami dengan 19 peserta didik menjawab "Ya", (d) peta konsep mudah dipahami dengan 20 peserta didik menjawab "Ya", (e) ikon yang disajikan mudah dipahami dengan 19 peserta didik menjawab "Ya", (f) isi sesuai materi dengan 20 peserta didik menjawab "Ya", (g) produk menjadi solusi ketebatasan dengan 20 peserta didik menjawab "Ya". (3) bahasa, dimana mendapatkan presentase 92,5\% karena terdapat aspek bahasa mudah dipahami dengan 20 menjawab "Ya" dan aspek istilah bahan ajar mudah dipahami dengan 17 menjawab "Ya". (4) grafis, dimana mendapatkan presentase 97,5\% karena terdapat aspek meliputi: (a) desain cover menarik dengan 20 jawaban "Ya", (b) desain tampilan menarik dengan 17 jawaban "Ya", (c) jenis huruf jelas mudah dibaca dengan 20 jawaban "Ya", (d) kombinasi warna yang menarik dengan 20 jawaban "Ya", (e) gambar dan ilustrasi mempermudah pemahaman dengan 20 jawaban "Ya", (f) gambar dan ilustrasi mendorong minat membaca dengan 20 jawaban "Ya". Jadi, dari analisis tersebut mendapatkan hasil bahwa: (1) produk mudah dipahami oleh peserta didik, (2) tertarik untuk memperlajarinya, (3) meningkatkan motivasi memperlajari materi, (4) kesesuaian materi, (5) sebagai solusi keterbatasan bahan ajar. Hal ini menunjukkan kesesuaian dengan hasil penelitian Tania dan Susilowibowo (2017) bahwa dalam komponen berupa: (1) kelayakan penyajian memperoleh 98\%, dimana terdapat aspek meliputi: (a) peserta didik tertarik, (b) termotivasi untuk belajar. (2) kelayakan bahasa memperoleh $85 \%$, dimana terdapat aspek meliputi: (a) peserta didik memahami kalimat dan bahasa, (b) istilah mudah dipahami, (c) pemberian kata dengan menggunakan bahasa asing juga disertai artinya dalam bahasa Indonesia. (3) kelayakan grafis memperoleh 92\%, dimana karena aspek: (a) ketertarikan terhadap aplikasi, (b) fitur petunjuk penggunaan yang mudah dipahami. Oleh karena itu, rata-rata presentase produk 93\% dengan kriteria sangat baik. Lalu sesuai dengan hasil penelitian dari Chairudin (2021) dimana terdapat peningkatan hasil belajar karena aspek meliputi: (a) materi yang mudah dimengerti, (b) membangkitkan motivasi belajar, (c) dapat berpikir kritis. Oleh karena itu, rata-rata presentase produk 95,5\%. Adapun penelitian yang dilakukan oleh peneliti terbatas karena menghasilkan produk berupa e-book berbasis flipbook sehingga harapan peneliti untuk penelitian selanjutnya dapat menggunakan produk lainnya. Terdapat makna penelitian terhadap ilmu keimuan ini, dimana dengan produk berbasis IT tersebut dapat membantu pendidik untuk lebih kreatif dalam menciptakan pembelajaran sehingga saat sedang pembelajaran jarak jauh dapat dengan mudah membuat inovasi terbaru. Hal ini diperkuat oleh observasi awal bahwa pendidik belum pernah membuat produk berbasis elektronik, serta bergantung dengan bahan ajar cetak saja.

\section{KESIMPULAN}

Berdasarkan kesimpulan bahwa e-book berbasis flipbook materi PPh pasal 21 ditujukan bagi XI AKL 2 SMK Negeri 2 Buduran Sidoarjo. Peneliti menggunakan tahapan define, design, dan development. Proses 
2230 Pengembangan Bahan Ajar E-Book Berbasis Flipbook sebagai Pendukung Pembelajaran Administrasi Pajak dengan Kompetensi Dasar PPh Pasal 21 - Anisah Candra Meidita, Joni Susilowibowo

DOI: https://doi.org/10.31004/edukatif.v3i5.784

kelayakan bahan ajar telah mendapatkan rata-rata 3 ahli dengan kriteria sangat layak sehingga produk tersebut dapat digunakan. Analisis dan perhitungan tersebut didapatkan dari isian lembar validasi yang telah diisi oleh 3 validator. Respon peserta didik mendapatkan rata-rata dengan kriteria sangat memahami karena didapatkan dari hasil analisis dan perhitungan melalui penyebaran angket sehingga dari hasil tersebut produk dapat dijadikan pendukung pembelajaran.

\section{UCAPAN TERIMA KASIH}

Peneliti mengucapkan terima kasih ke berbagai pihak yang memberikan dukungan berupa tindakan ataupun do'a. Semoga artikel ini dapat dijadikan salah satu acuan untuk penelitian selanjutnya.

\section{DAFTAR PUSTAKA}

Bsnp. (2014). Instrumen Penilaian Buku Teks Pelajaran Sma/Ma Komponen Kelayakan Kegrafikan. Badan Standar Nasional Pendidikan. Https://Bsnp-Indonesia.Org/2014/05/Instrumen-Penilaian-Buku-TeksPelajaran-Tahun-2014/

Chairudin, M. (2021). Pengembangan Bahan Ajar Buku Saku Digital Berbasis Problem Based Learning Pada Mata Pelajaran Ekonomi. Edukatif: Jurnal Ilmu Pendidikan, 3(3), 951-962. Https://Doi.Org/Httpsdoi.Org10.31004edukatif.V3i3.491

Dewi, D. R., \& Rohayati, S. (2012). Pengembangan Bahan Ajar E-Book Interaktif Materi Jurnal Khusus Akuntansi Perusahaan Dagang Berbasis Scientific Approach Sebagai Sumber Belajar Alternatif Kelas Xi Smk Negeri 2 Buduran Sidoarjo. Jurnal Pendidikan Akuntansi, 01(01), 0-216.

Fitriani, I., \& Rohayati, S. (2019). Pengembangan E-Book Berbasis Android Dengan Pendekatan Saintifik Pada Mata Pelajaran Administrasi Pajak Kelas Xii Akuntansi Di Smk Negeri 2 Buduran. Jurnal Pendidikan Akuntansi, 7(1), 11-20.

Hamid, A. (2021). Pentingnya Mengembangkan E-Modul Interaktif Berbasis Flipbook Di Sekolah Menengah Atas. Edukatif: Jurnal Ilmu Pendidikan, 3(3), 911-918. Https://Doi.Org/Https://Doi.Org/10.31004/Edukatif.V3i3.452

Hosnan. (2016). Pendekatan Saintifik Dan Kontekstual Dalam Pembelajaran Abad 21 (R. Sikumbang (Ed.); Cet 3). Ghalia Indonesia.

Kirana, R. W. C., \& Susilowibowo, J. (2020). Pengembangan Bahan Ajar E-Book Praktikum Akuntansi Perusahaan Dagang Berbasis Scientific Approach Sebagai Sumber Belajar Alternatif. Jurnal Pendidikan Akuntansi Indonesia, 18(1), 80-90. Https://Doi.Org/Https://Doi.Org/10.21831/Jpai.V18i1.32292

Majid, A. (2017). Perencanaan Pembelajaran (Mukhlis (Ed.)). Pt Remaja Rosdakarya. Www.Rosda.Co.Id

Masithoh, D. (2018). Teachers' Scientific Approach Implementation In Inculcating The Students' Scientific Attitudes. Jurnal Prima Edukasia, Https://Doi.Org/Https://Doi.Org/10.21831/Jpe.V6i1.14282

Michael F. Suarez, S. J., \& Wooudhuysen, H. R. (2013). The Book A Global History (P. 271). Oxford University Press.

Pratiwi, A. Z., \& Rochmawati. (2019). Pengembangan Bahan Ajar E-Book Interaktif Pendekatan Kurikulum 2013 Mata Pelajaran Praktikum Akuntansi Lembaga/Instansi Pemerintah Kelas Xi Akl Smk Negeri 1 Lamongan. Jurnal Pendidikan Akuntansi, 7(2), 1-7.

Rahmawati, S., \& Susanti. (2019). Pengembangan Bahan Ajar E-Book Pada Mata Pelajaran Praktikum Akuntansi Lembaga Berbasis Kontekstual Untuk Smk. Jurnal Pendidikan Akuntansi, 7(3), 383-391.

Riduwan. (2003). Skala Pengukuran Variabel-Variabel Penelitian (D. P. D. Iswara (Ed.); Cetakan 2). 
2231 Pengembangan Bahan Ajar E-Book Berbasis Flipbook sebagai Pendukung Pembelajaran Administrasi Pajak dengan Kompetensi Dasar PPh Pasal 21 - Anisah Candra Meidita, Joni Susilowibowo

DOI: https://doi.org/10.31004/edukatif.v3i5.784

Alfabeta.

Rostika, D., \& Prihantini. (2019). Pemahaman Guru Tentang Pendekatan Saintifik Dan Implikasinya Dalam Penerapan Pembelajaran Di Sekolah Dasar. Eduhumaniora: Jurnal Pendidikan Dasar, 11(1), 86-94. Https://Doi.Org/Https://Doi.Org/10.17509/Eh.V11i1.14443

Rumahlatu, D., Huliselan, E. K., \& Takaria, J. (2016). An Analysis Of The Readiness And Implementation Of 2013 Curriculum In The West Part Of Seram District, Maluku Province, Indonesia. International Journal Of Environmental \& Science Education, 11(12), 5662-5675.

Sa'diyah, K. (2021). Pengembagan E-Modul Berbasis Digital Flipbook Untuk Mempermudah Pembelajaran Jarak Jauh Di Sma. Edukatif: Jurnal Ilmu Pendidikan, 3(4), 1298-1308. Https://Doi.Org/Https://Doi.Org/10.31004/Edukatif.V3i4.561

Sukiman. (2012). Pengembangan Media Pembelajaran (M. A. Salmulloh (Ed.); 1st Ed.). Pedagogia.

Tania, L., \& Susilowibowo, J. (2017). Pengembangan Bahan Ajar E-Modul Sebagai Pendukung Pembelajaran Kurikulum 2013 Pada Materi Ayat Jurnal Penyesuaian Perusahaan Jasa Siswa Kelas X Akuntansi Smk Negeri 1 Surabaya. Jurnal Pendidikan Akuntansi, 5(2), 1-9.

Trianto. (2017). Mendesain Model Pembelajaran Inovatif, Progresif, Dan Kontekstual (Jefry (Ed.); Cet Ke-3). Kencana.

Uno, H. B. (2011). Model Pembelajaran: Menciptakan Proses Belajar Mengajar Yang Kreatif Dan Efektif(F. Yustianti (Ed.); Ed. 1, Cet). Bumi Aksara.

Widiyawati, L., \& Susanti. (2017). Pengembangan Modul Administrasi Pajak Berbasis Kontekstual Pada Materi Pajak Penghasilan (Pph) Pasal 21 Untuk Siswa Kelas Xii Akuntansi Smk Negeri Di Surabaya. Jurnal Pendidikan Akuntansi, 5(1), 1-7.

Yulaika, N. F., Harti, \& Sakti, N. C. (2020). Pengembangan Bahan Ajar Elektronik Berbasis Flip Book Untuk Meningkatkan Hasil Belajar Peserta Didik. Jurnal Pendidikan Ekonomi, Manajemen Dan Keuangan, 4(1), 67-76. Https://Doi.Org/10.26740/Jpeka.V4n1.P67-76 